\title{
Academic Certificate Fraud Detection System Framework Using Blockchain Technology
}

\author{
Ninda Lutfiani ${ }^{1}$, Desy Apriani ${ }^{2}$,Efa Ayu Nabila ${ }^{3}$, Hega Lutfilah Juniar ${ }^{4}$ \\ University Of Raharja $1,2,3,4$ \\ Jl. Jenderal Sudirman No.40, RT.002/RW.006, Cikokol, Kec. Tangerang, Kota Tangerang, \\ Banten 15117,2,3 \\ e-mail: ninda@raharia.info', ${ }^{1}$ desy@raharja.info ${ }^{2}$, efaayunabila@raharia.info ${ }^{3}$, \\ hega.Iutfilah@raharia.info ${ }^{4}$
}

Lutfiani , N., Apriani , D., Nabila , A.E, Sari , A.A, Febrianto , K.R, Decentralization Of Information Using Blockchain Technology On Mobile Apps E-Journal Blockchain Frontier Technology (B-Front), 1(2), 55-64.

DOI: https://journal.pandawan.id/b-front/article/view/37

\begin{abstract}
The era of rapid disruption was accompanied by increased crime in data falsification and interception. The philosophy of Blockchain technology is related to its ontology; it can be characterized, applied, and realized by how it works in the world of education. Blockchain technology is used to verify the authenticity of academic degrees and certificates. Systems that use digital signature schemes and implementation timestamps in the development of blockchain technology use blockchain software. The impact of falsifying educational documents results in workers not being qualified for a particular position. The main interest of this service is to balance between graduates and employers by minimizing crime and falsifying educational documents. The method used in this research is a literature study from previous studies. As a result of maximizing the potential of blockchain technology, fees can also lead to checking the authenticity of certificates through trusted sources. The application and utilization of blockchain in the academy certificate fraud detection system can be a means of offering problems that exist from a global perspective and other stakeholders.
\end{abstract}

Keywords: Blockchain, Framework, authenticity, diploma

\section{Introduction}

Having academic sacredness, a diploma can be a unique marker for completing his education. It can be said that they are deemed worthy and are also allowed to receive, use the education certificate they have as stated in the national education system Article 67: paragraph (1) in Law No. 20 of 2003 [1]. The punishment is in the form of imprisonment with a maximum of ten years and a maximum fine of Rp. 1,000,000,000.00 (one billion rupiahs) will be given to individuals, organizations, or educational institutions that provide diplomas, certificates of competence, academic, professional, and vocational degrees without rights [2]. The rapid development of technology supports increasingly diverse crimes. One of them is the crime of falsifying educational documents. Crime in the form of fraud, counterfeiting is increasingly happening [3].

The rapid development of technology has triggered a digital revolution. If technological developments support the rapidity of crime, then prevention is very much needed [4]. It is undeniable that the development of blockchain technology is swift. The potential for blockchain technology is relatively high in technological change. Blockchain is arguably a peer-to-peer 
transaction record connected in a decentralized manner, with a cryptographic technique on every transaction in it [5]. A third party (third party) is not required for every blockchain transaction in the process. Blockchain is structured data; from structured data, this will allow the birth of a digital ledger in an independent network so that the data in it can be shared and connected. With blockchain technology, the advantage is more felt than a centralized database.

Blockchain is publicly distributed [6]. This is possible because Blockchain is indeed a transparent transaction ledger. Blockchain is decentralized and permissionless [7]. The emergence of blockchain technology is arguably a boon because the transparency of data on the Blockchain makes the collection process possible information, distribution, and processing of information more secure [8]. In short, Blockchain is a distributed database. Every computer network will be connected from one computer to another. The application of blockchain technology in education is very much needed. You could say Blockchain seems to be a beacon, a revolutionary solution amid educational polemics that often occur. This technology can be the best means of validating the authenticity of educational documents that often experience forgery because it takes a long time when the company confirms and validates the certificate's validity manually. Significant time cuts accompanied by a reduction in the rate of counterfeiting are the selling points of blockchain technology [9]. The allocation of blockchain technology utilization will focus on this research to reduce crime and prevent counterfeiting [10].

\section{-Internal Deposit:}

Fraud is carried out based on the application to the academic record of an educational institution that has passed even if the individual fails to pass or credentials. Not only done individually, but fraud can also enter the part of academic institutions [11]. Using the time stamp next to the digital signature on each diploma is the best way to prove the authenticity of graduation. The creation of false titles can be avoided in this way and requires the availability and trust of a third party (Time Stamping Authority) that validates the date regardless of cost issues with conventional timestamp technology. At this point, time accuracy on many blockchains is far from ideal. However, it is still sufficient because the time needed is no longer in a matter of days but in minutes or even seconds when the certificate is signed. The application of the cryptographic hash function will be applied to the diploma, which will then be recorded on the public blockchain with transactions that the academic institution digitally signs [12]. Decisions in implementing Blockchain Technology are considered a means of increasing security in education certificates in entering the digital era 4.0. Simplification in the use of blockchain can be considered a solution; of course, it is more economical, it can also be a means of fixing existing shortcomings. With the decentralized nature of blockchain, the date on which information is recorded will be irreversible and publicly verifiable. This will create trust because it does not go through an intermediary process. With this, it can be concluded that the use of blockchain can provide a timely and accurate solution. In addition, thanks to the widespread use of cryptocurrency, blockchain is straightforward and trustworthy [13]. 
- Blockchain Technology in Verifying the Authenticity of Educational Certificates:

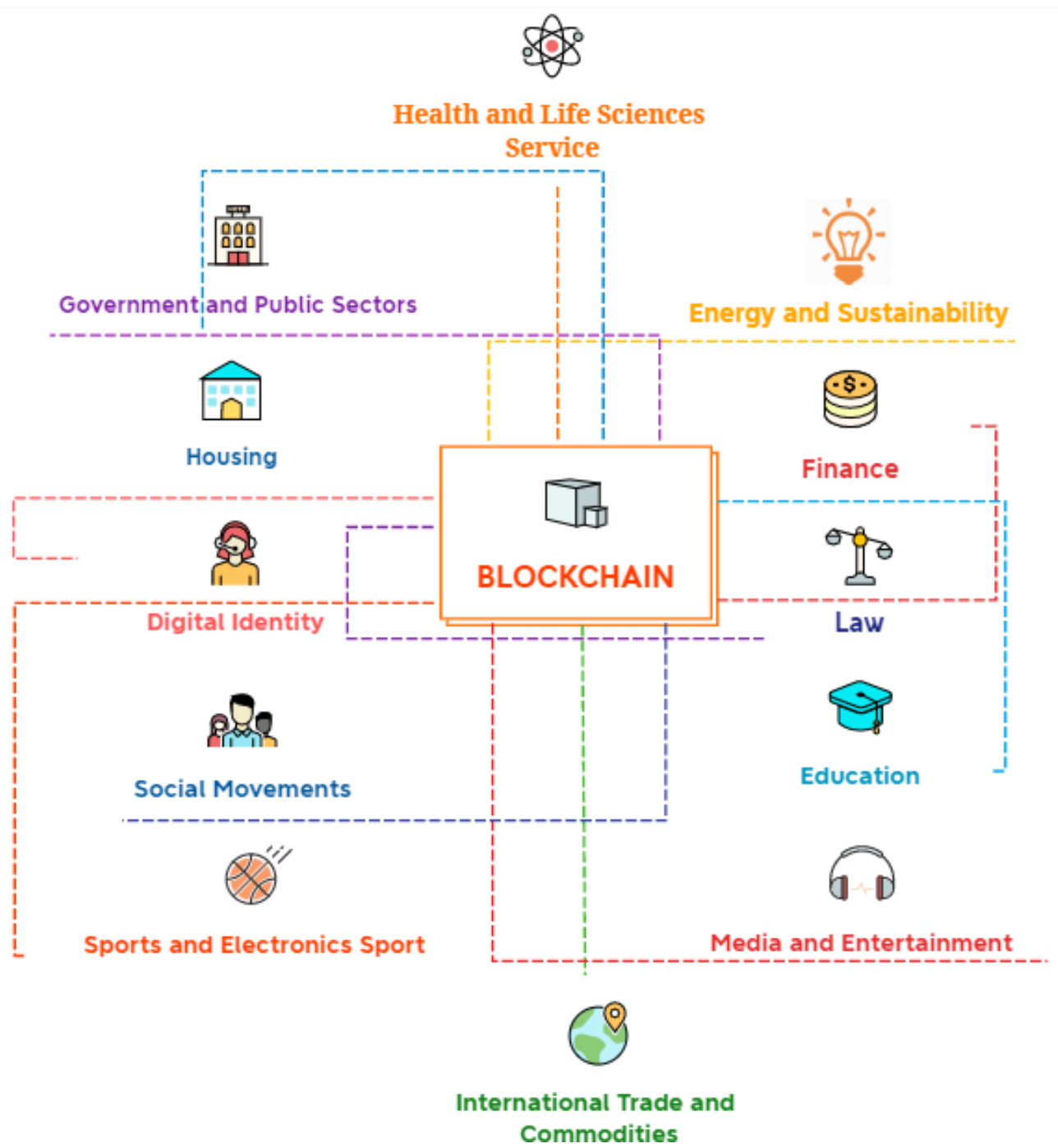

Figure 1. Blockchain Utilization Field

The blockchain data structure itself is like a blockchain that continues to develop with cryptographic hashes; this process continues, and records transactions also undergo a storage process, which tracks and collects data in the blockchain network. You could say blockchain provides immutable data storage[14]. Blockchain is digital decentralization. Of course, this can prevent revisions and only allow transactions to be entered without updating or deleting any transactions on the blockchain. Blockchain technology is implemented in areas such as Health Services, Energy, Finance, Law, Education, Media and Entertainment, International Trade, Sports, Social Movements, Digital Identity, Housing, and the Sector, Public Government[15].

In education, the use of blockchain is one of the pioneers of technological development. Everyone seems to be competing to complete their education in the Regulation of the Minister of Education and Culture of the Republic of Indonesia No. 81 of 2014, which explains that a certificate is clear evidence of the completion of the education level and is a document of recognition of learning achievement held by universities. Having a diploma can arguably increase the chances of holding important positions in work [16]. Therefore, a high formal level diploma is considered quite important for most people. 
The importance of a thing will lead to higher crime and fraud. Certificate falsification is increasingly happening. Based on data from Media Indonesia, the production of certificates from private campuses in Tangerang City, Banten, has reached 873 certificates. This is inversely proportional to the fact where only 145 students successfully graduated. It can be concluded that as many as 728 certificates without credibility have been produced. Another incident occurred in North Sumatra where a candidate for Governor was declared to have forged legalized photocopies of his diploma. Caught in violation of the election provisions, he withdrew from his candidacy [17]. The high level of falsification makes the credibility of the certificate even more doubtful; prevention and increased security are increasingly needed.

\section{Theoretical framework}

By using blockchain technology, this research discusses the problem, the security of education certificates. Counterfeit certificates have become more widespread; many fake certificates are used to apply for jobs. The widespread use of fake certificates has made certificates no longer prove a person's expertise or skills as proof [18].

Troubleshooting the certificate verification system and stopping fraud is the main focus of this research. The ease of counterfeiting education certificates at low costs is very unsettling and detrimental to universities or related educational institutions. Validation of the authenticity of a diploma in a company also requires a lot of time and money. This is due to the lengthy process the company undertakes. Submit applicants' files to the agency to validate the authenticity of the diploma before being sent back to the company. The decline in Human Resources (HR) in Indonesia is experiencing an impact due to the inappropriate placement of important positions in several professions. Blockchain is considered to be the answer to existing problems [19]. The use of blockchain technology can be an obstacle for specific individuals. This project evaluates blockchain applications for implementing distributed systems as a service.

In recent years, the reference capacity of using blockchain in education has increased. The decline in public interest in taking formal education is one of the results of certificate forgery. Increasing the security system through blockchain technology in its implementation. In improving the certificate security system, universities are expected to adopt blockchain. The use of the certificate function as a printed certificate can be a proof, in the form of the right to the achievements of students.

\section{Method}

This research was conducted using 2 (two) research methods, namely the Descriptive Method and Literature Study Method: Descriptive research is research in uncovering independent variables, either one or more variables [20]. It can be concluded that the descriptive method describes a problem that will be examined as a method, which aims to provide information based on the problems of the research process and the placement of appropriate information about the problems of the research being carried out.

Literature study is a method driven by the similarity of research topics from various books, scientific journals, literature, and expert opinions. The literature study method can facilitate writing using various information based on existing references and data from previous research. Research collection with related themes is carried out to become a means of further research. Here are 7 (seven) related literature studies, namely:

1. No single entity can control the blockchain. The use of the same information blocks supports this claim [21].

2. Storing data on the blockchain network is considered to reduce the negative impact on technological development [22].

3. For a student, an educational certificate is considered very important and valuable. This is due to a certificate proof of one's participation in education. It is essential to increase security measures in preventing counterfeiting of educational certificates [23].

4. In the research that Muhammad Suharto has conducted from Kanjuruhan University Malang in the Journal of Educational Inspiration with the use of the title "The Influence of Technology Development on New Student Admissions at Junior High Schools with 
Integration of Diploma Number Validation," Discussing the need for a diploma to continue education at the next level, In preventing the occurrence of illegal acts, namely changing and manipulating the authenticity of diplomas, improving the certificate authenticity verification system is needed [24].

5. This research discusses the advantages of blockchain, namely a high level of security to secure data; this reminds us of prevention in using data by irresponsible people.

6. Data on the blockchain can only be updated if all parties involved in the transaction agree to update. This makes the blockchain a continuously growing, secure, shared record storage system in which every data user keeps a copy of the records [25].

7. In the certificate validation system study, intelligent contracts were carried out to store diplomas on the blockchain, which had attributes including the address of the certificate owner, agency, and image of the certificate [26].

\section{Results and Discussion}

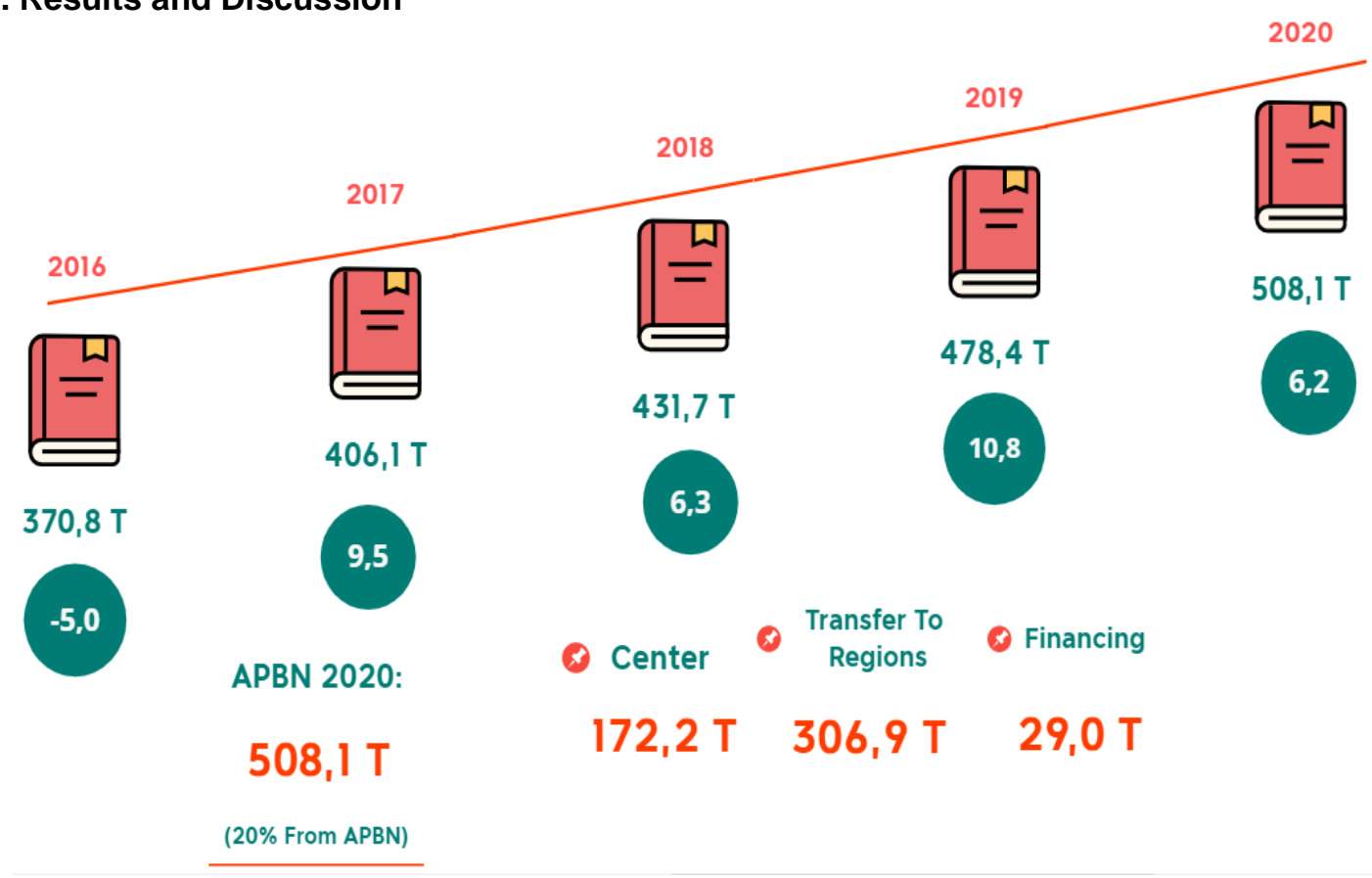

Figure 2. Percentage of APBN Funds in the Education Sector

The 2020 State Budget and Revenue (APBN) data in education shows a presentation of $6.2 \%$ with a total budget of $508.1 \mathrm{~T}$. An increase of $29.7 \mathrm{~T}$ from 2019. In addition, there are 123 PTN (State Universities). and 4,547 PTS (Private Universities) with a total of 4,670 PT (Universities) in Indonesia. This makes the field of education considered appropriate in implementing blockchain technology. So many diplomas are issued each year [27]. Along with this, counterfeiting educational certificates in the form of diplomas is easier to be accompanied by cheap costs. This led to difficulties in the authenticity validation system. High costs are required in recruiting workers, including validating the authenticity of the certificate. It is not uncommon to find fraud in the recruitment process. The fraud that occurred even reached $25 \%$ in the form of certificate forgery. This fraud has an impact on placing positions on less competent people [28]. 


\subsection{Conventional Validation}

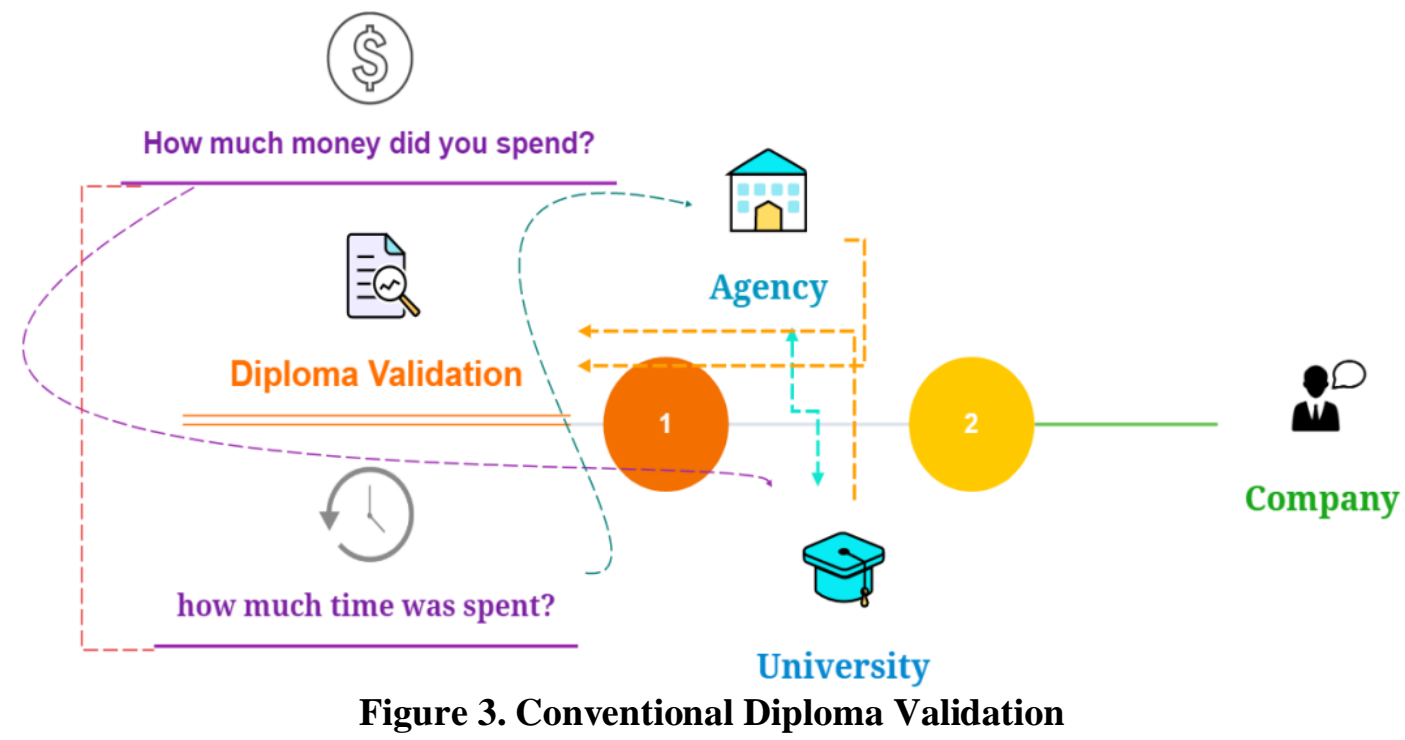

Figure 3 (three) shows the flow of checking the diploma's authenticity without interference from blockchain technology. Verification of the authenticity of the certificate data is carried out by making direct contact with the party making the certificate regarding the authenticity of the diploma and a signed legalization process from the party making the certificate [29]. The process begins with the company sending the relevant documents to the institution, then proceeding to the University to verify the diploma's authenticity. Signatures and stamps will be given as proof of the diploma's authenticity, then the University will send the document back to the agency, and the agency will again send the document to the company [30]. We can see how much time was wasted in the validation process. The complicated process takes much time and costs a lot to verify the diploma's authenticity. In addition, validating the authenticity of this diploma cannot produce results within one day. The transformation of the diploma validation flow must be developed for effectiveness in the certificate validation process, which is very much needed. A method that creates certainty is badly needed. In this research, the focus will be on the use of blockchain technology in education to increase the effectiveness of the education certificate verification process [31] 


\subsection{Blockchain System Validation}

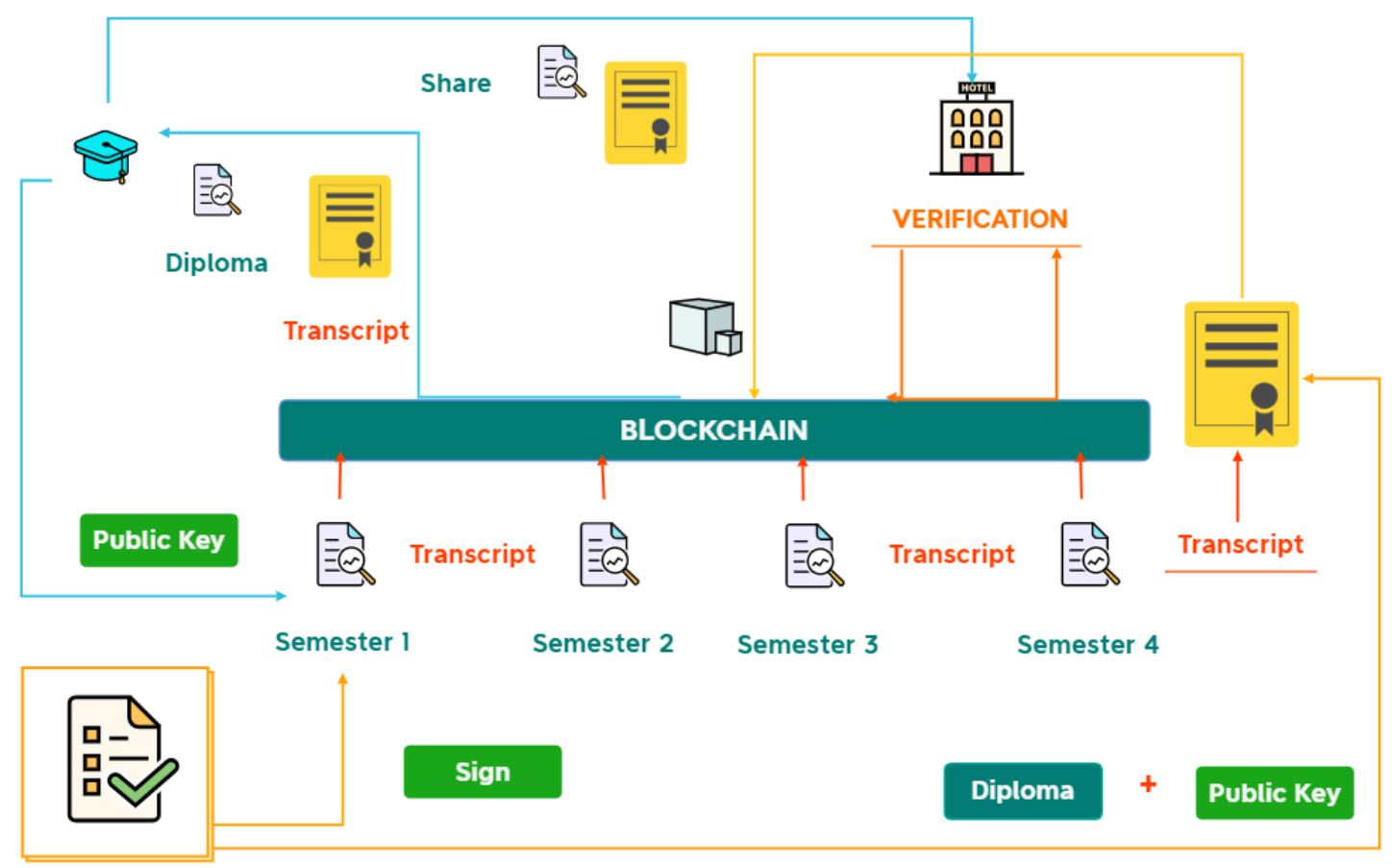

Figure 4. Certificate Validation Using Blockchain Technology

Figure 4 (four) shows the use of blockchain technology in education. We can see the implementation of blockchain technology by issuing a diploma on the blockchain after officially graduating from university [32]. After entering the process of issuing a diploma on the blockchain, the certificate will be transparent in authenticity. It is easy to prove the diploma's authenticity when the job application process is carried out. The certificate authenticity data comes from data on the blockchain uploaded to the blockchain system [33].

\subsection{Characteristics of the Blockchain System}

The characteristics of the blockchain are like a block. Blockchain will dial according to the id number (hash); blocks will not connect into a chain if the id numbers are not the same and match. Blockchain has code in the agreement process; this is due to the nature of the blockchain, which is like an intelligent contract; both parties can no longer do counterfeiting [34]. The negative impact of technology is not so significant if its use is right on target, including the intended use and the time of use is regulated in such away. The use of blockchain technology can reduce or even prevent issuing fake diplomas. This is due to the blockchain system provided by the university. Transparency can reduce the risk of fraud and forgery in the system. Not only that, but the use of blockchain technology also increases time and cost-effectiveness [35].

\section{Conclusion}

The use of blockchain technology in education is a good and right decision. The efficiency of a system that is less flexible is a must. There are 4 (four) problem descriptions can be resolved with 4 (four) conclusions: First, the emphasis on diploma counterfeiting can be overcome by using blockchain technology. The increasing percentage of difficulty in counterfeiting a certificate will increase. Second, the use of blockchain technology can reduce costs. It will be easier and cheaper to verify the authenticity of a candidate's certificate. Third, 
the efficiency of time, energy, and costs are essential in applying blockchain technology. The certificate authenticity verification process will not take long; in a matter of minutes, the verification process can be completed. Fourth, the most critical impact is the competence of workers. The use of blockchain technology produces qualified and competent workers. Of course, it is blockchain technology that makes it difficult to fake a certificate.

In education, blockchain technology is vital and needed in Indonesia, given the many advantages that exist. Unfortunately, the implementation of blockchain technology in education is still adjusting, considering its lack of acceptance in society. Socialization about the benefits of implementing blockchain technology is needed.

\section{Acknowledgements}

This research was financially supported by the Ministry of Research and Technology/BRIN based on Grants number 16/E1/KPT/2020 and number 8/E1/KPT/2021 concerning Determination of Research Funding at State Universities Legal Entities. The authors express their gratitude to the Raharja College, which has provided support, facilities, and financially so that the authors can complete this research correctly.

\section{References}

[1] K. Kumutha and S. Jayalakshmi, "Hyperledger Fabric Blockchain Framework: Efficient Solution for Academic Certificate Decentralized Repository," in 2021 Fifth International Conference on I-SMAC (IOT in Social, Mobile, Analytics and Cloud)(I-SMAC), 2021, pp. 1584-1590.

[2] M. Yusup, Q. Aini, D. Apriani, and P. Nursaputri, "PEMANFAATAN TEKNOLOGI BLOCKCHAIN PADA PROGRAM SERTIFIKASI DOSEN," in SENSITIf: Seminar Nasional Sistem Informasi dan Teknologi Informasi, 2019, pp. 365-371.

[3] D. Julianingsih, A. G. Prawiyogi, E. Dolan, and D. Apriani, "Utilization of Gadget Technology as a Learning Media," IAIC Trans. Sustain. Digit. Innov., vol. 3, no. 1, pp. 43-45, 2021.

[4] C. L. Kusnadi, N. Lutfiani, H. L. Juniar, and U. Rahardja, "Miu ai: Application based on the e-commerce prototype for japanese otaku in indonesia," J. Adv. Res. Dyn. Control Syst, vol. 12, no. 6, pp. 618-623, 2020.

[5] D. Supriyanti, M. I. Sanni, A. Asmawati, and F. M. Suryaman, "Inovasi Smart Contract dan Tokenisasi Berbasis Blockchain pada Pendidikan Tinggi."

[6] M. R. Anwar, D. Apriani, and I. R. Adianita, "Hash Algorithm In Verification Of Certificate Data Integrity And Security," Aptisi Trans. Technopreneursh., vol. 3, no. 2, pp. 65-72, 2021.

[7] N. Lutfiani, W. S. Mariyati, A. A. Sari, and K. R. Febrianto, "Decentralization Of Information Using Blockchain Technology On Mobile Apps E-Journal," Blockchain Front. Technol., vol. 1, no. 2, pp. 114-121, 2022.

[8] Q. Aini, "HAK MEMESAN EFEK TERLEBIH DAHULU DALAM PERSPEKTIF HUKUM BISNIS SYARI'AH," Az Zarqa' J. Huk. Bisnis Islam, vol. 11, no. 2, 2019.

[9] U. Rahardja, Q. Aini, F. Budiarty, M. Yusup, and A. Alwiyah, "Socio-economic impact of Blockchain utilization on Digital certificates," Aptisi Trans. Manag., vol. 5, no. 2, pp. 106111, 2021.

[10] B. P. K. Bintoro, N. Lutfiani, and D. Julianingsih, "Analysis of the Effect of Service Quality on Company Reputation on Purchase Decisions for Professional Recruitment Services," APTISI Trans. Manag., vol. 7, no. 1, pp. 35-41, 2023.

[11] N. Lutfiani, U. Rahardja, and K. T. Khasanah, "The Development Viewboard As an Information Media at Official Site Asosiation," APTISI Trans. Manag., vol. 6, no. 1, pp. 10-18, 2022.

[12] S. Saprudin, Q. Aini, and A. M. P. Napitupulu, "PERLAKUAN AKUNTANSI ATAS SELISIH KURS DALAM TRANSAKSI MATA UANG ASING TERHADAP LABA BERSIH PADA PT. DIANTA MITRAFAIRINDO INTERNASIONAL," J. Akunt. dan Perpajak. Jayakarta, vol. 3, no. 1, pp. 30-43, 2021. 
[13] U. Rahardja, Q. Aini, A. Khairunisa, and S. Millah, "Implementation of Blockchain Technology in Learning Management System (LMS)," APTISI Trans. Manag., vol. 6, no. 2, pp. 112-120, 2022.

[14] A. G. Prawiyogi, Q. Aini, N. P. L. Santoso, N. Lutfiani, and H. L. J. Juniar, "Blockchain Education Concept 4.0: Student-Centered iLearning Blockchain Framework," JTP-Jurnal Teknol. Pendidik., vol. 23, no. 2, pp. 129-145, 2021.

[15] A. K. Samanta, B. B. Sarkar, and N. Chaki, "A blockchain-based smart contract towards developing secured university examination system," J. Data, Inf. Manag., pp. 1-13, 2021.

[16] X. Liu, "Exploration \& Research on Distance Education System Based on Blockchain Technology," in Journal of Physics: Conference Series, 2021, vol. 1769, no. 1, p. 12041.

[17] U. Rahardja, N. Lutfiani, and H. L. Juniar, "Scientific Publication Management Transformation In Disruption Era," Aptisi Trans. Manag., vol. 3, no. 2, pp. 109-118, 2019, doi: $10.33050 /$ atm.v3i2.1008.

[18] A. Khoirunnisa, A. S. Rafika, and H. L. Juniar, "Eksistensi Sistem Pendidikan Islam Dalam Implementasi Pemanfaatan Teknologi Informasi Pada Era 4.0," Alph. J. Wawasan Agama Risal. Islam. Teknol. dan Sos., vol. 1, no. 1, pp. 26-35, 2021.

[19] R. Dharmalingam, H. Ugail, A. N. Shivasankarappa, and V. Dharmalingam, "Framework for Digitally Managing Academic Records Using Blockchain Technology," in Mobile Computing and Sustainable Informatics, Springer, 2022, pp. 633-645.

[20] G. Maulani, G. Gunawan, L. Leli, E. A. Nabila, and W. Y. Sari, "Digital Certificate Authority with Blockchain Cybersecurity in Education," Int. J. Cyber IT Serv. Manag., vol. 1, no. 1, pp. 136-150, 2021.

[21] Q. Aini, N. Lutfiani, and M. S. Zahran, "Analisis Gamifikasi iLearning Berbasis Teknologi Blockchain," ADI Bisnis Digit. Interdisiplin J., vol. 2, no. 1, pp. 79-85, 2021.

[22] A. Ali, "University of Cumberlands Blockchains applications paper."

[23] N. Priya, M. Ponnavaikko, and R. Aantonny, "An efficient system framework for managing identity in educational system based on blockchain technology," in 2020 International Conference on Emerging Trends in Information Technology and Engineering (ic-ETITE), 2020, pp. 1-5.

[24] I. Handayani, R. Supriati, and E. S. N. Aisyah, "Proof of Blockchain Work on The Security of Academic Certificates," in 2020 8th International Conference on Cyber and IT Service Management (CITSM), 2020, pp. 1-5.

[25] M. J. R. Mahale and E. M. Chirchi, "GENERATION OF EDUCATIONAL DOCUMENTS USING BLOCKCHAIN FRAMEWORK," Int. J., vol. 6, no. 4, 2021.

[26] S. Balasubramanian, V. Shukla, J. S. Sethi, N. Islam, and R. Saloum, "A readiness assessment framework for Blockchain adoption: A healthcare case study," Technol. Forecast. Soc. Change, vol. 165, p. 120536, 2021.

[27] R. F. Nevizond, U. Rahardja, N. P. L. Santoso, S. Purnama, and W. Y. Prihastiwi, "Collaboration Blockchain Technology and Gamification in iLearning systems," Sci. J. Informatics, vol. 8, no. 2, pp. 213-221, 2021.

[28] T. Nurhaeni, L. Nirmalasari, A. Faturahman, and S. Avionita, "Transformation Framework Design on Digital Copyright Entities Using Blockchain Technology," Blockchain Front. Technol., vol. 1, no. 01, pp. 35-43, 2021.

[29] T. Hariguna, Y. Durachman, M. Yusup, and S. Millah, "Blockchain Technology Transformation in Advancing Future Change," Blockchain Front. Technol., vol. 1, no. 01, pp. 13-20, 2021.

[30] C. Choiriyah, N. Lutfiani, A. Khoirunisa, A. Faturahman, and E. A. Nabila, "Science Literacy in Early Childhood: Development of Learning Programs in the Classroom," Indones. J. Early Child. Educ. Stud., vol. 10, no. 2, pp. 136-142, 2021.

[31] Q. Aini, E. P. Harahap, and F. Faradilla, "The Effects of Sales Reports Business Intelligence on Employee Performance," Aptisi Trans. Manag., vol. 4, no. 1, pp. 83-91, 2020.

[32] K. Kumutha and S. Jayalakshmi, "Blockchain Technology and Academic Certificate Authenticity-A Review," Expert Clouds Appl., pp. 321-334, 2022.

[33] N. Lutfiani, Q. Aini, U. Rahardja, L. Wijayanti, E. A. Nabila, and M. I. Ali, "Transformation of blockchain and opportunities for education 4.0," Int. J. Educ. Learn., vol. 3, no. 3, pp. 
222-231, 2021

[34] I. K. Gunawan, N. Lutfiani, Q. Aini, F. M. Suryaman, and A. Sunarya, "Smart Contract Innovation and Blockchain-Based Tokenization in Higher Education," J. Educ. Technol., vol. 5, no. 4, pp. 636-644, 2021.

[35] R. Widayanti, Q. Aini, H. Haryani, N. Lutfiani, and D. Apriliasari, "Decentralized Electronic Vote Based on Blockchain P2P," in 2021 9th International Conference on Cyber and IT Service Management (CITSM), 2021, pp. 1-7. 